\title{
Evaluation of colemanite as a slow release source of boron fertilizer for potato
}

\begin{tabular}{lll}
\hline Paper received: $14.11 .2017 \quad$ Revised received: $28.02 .2018 \quad$ Re-revised received: 30.05 .2018 & Accepted: 13.08 .2018
\end{tabular}

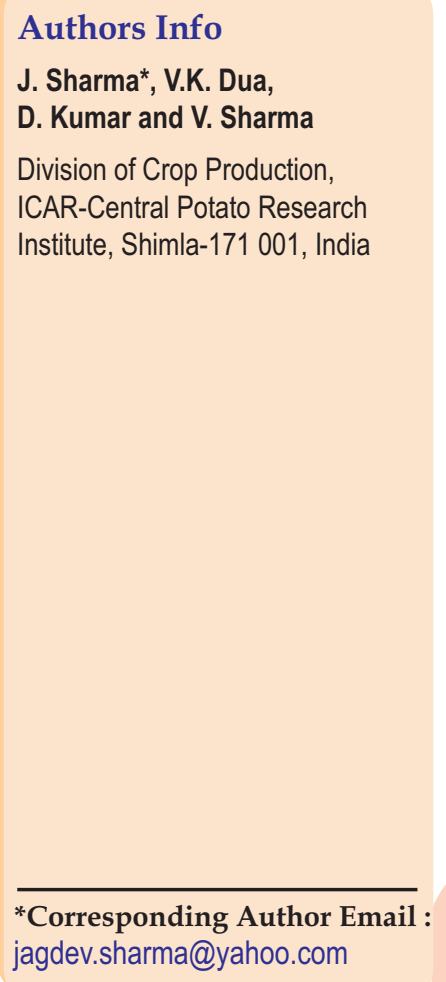

Edited by

Professor. Md. Rezaul Karim

Reviewed by

Dr. Asit Mandal

Dr. R. B. Raizada

\section{Abstract}

Aim : The present study was conducted with an objective to assess the suitability of colemanite $\left(\mathrm{Ca}_{2}\right.$ $\mathrm{B}_{6} \cdot \mathrm{O}_{11} \cdot 5 \mathrm{H}_{2} \mathrm{O}$ ) as a slow release source of boron to potato crop.

Methodology : Soil was incubated with boron (1.25 and $2.50 \mathrm{mg} \mathrm{kg}^{-1}$ soil) using borax and colemanite for six weeks. Soil moisture was maintained at $80 \%$ field capacity. Soil samples were analyzed weekly for hotwater extractable boron content. Direct and residual effects of borax and colemanite on potato plant growth and boron uptake were studied in pot experiments. Leaf boron concentration was measured by an ICP-OES.

Results : In laboratory incubation, although the rate of release of hot water extractable boron from colemanite was slower than borax, it was enough to meet the requirement of potato crop. Application of both the sources of boron increased its content significantly in soil as well as in potato leaves. This study revealed that boron uptake from colemanite was comparable to borax in meeting the boron requirement of potato.

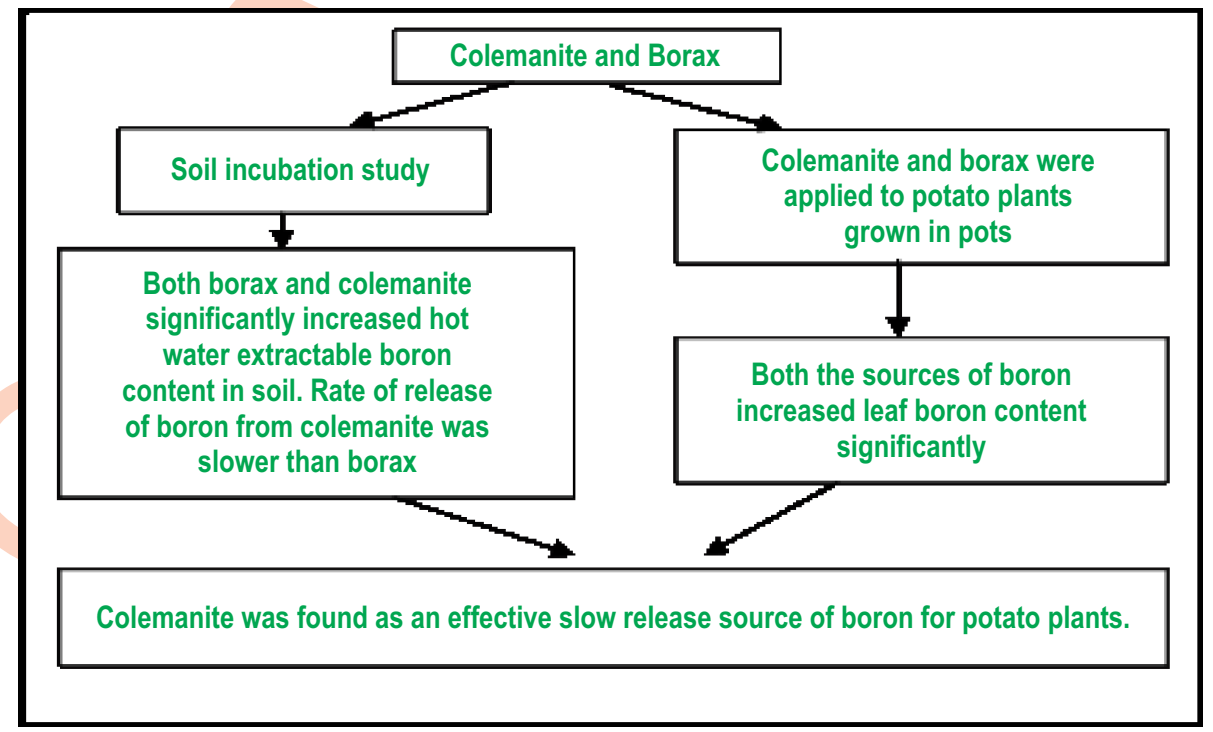

Interpretation : Soil incubation and pot experiment studies showed that colemanite is a suitable slow release source of boron fertilizer for potatoes.

Key words: Borax, Boron, Colemanite, Potato, Soil incubation, Solanum tuberosum

Citation: Sharma, J., V.K. Dua, D. Kumar and V. Sharma: Evaluation of colemanite as a slow release source of boron fertilizer for Potato (Solanum tuberosum L.). J. Environ. Biol., 40, 240-244 (2019). 


\section{Introduction}

Boron is an essential micronutrient required for several key growth processes in plants (Landi et al., 2012). It influences root and shoot growth, plant development. It is an essential micronutrient without which plants cannot complete their life cycle. In the cell wall it acts as cement between pectins and provides cohesive strength to cell tissues. It also affects calcium absorption, so its supply is important to ensure a balanced nutrition. Deficiency as well as toxicity of boron result in anatomical, biochemical and physiological changes in plants. Boron application has been found to decrease the reducing sugar content in potato (Hugo et al., 2007) and was found associated with increased endogenous IAA and ABA content (Muavviz et al., 2015). IAA plays an important role in the growth and development of plants, including cell division, expansion, differentiation, lateral root formation, flowering and tropic responses (Zhao et al., 2010). Boron is present in soil ranging 2 to $200 \mathrm{mg} \mathrm{kg}^{-1}$, however only less than $5 \%$ of total boron is available to plants due to less solubility of boron in soil and leaching. Potato is grown in light textured soils and boron appears to leach easily from surface soils (Sarkar et al., 2007). In a recent study conducted on potato growing soils, amongst the micronutrients, boron was reported to be the most deficient nutrient in the soil (Sharma et al., 2017).

Commonly used sources of boron like borax and boric acid are easily dissolved in soils and are quickly available for plant uptake, but at the same time boron can be leached from the root zone soil. In hilly areas, leaching due to rainfall is very high consequently regular application of boron is must. Colemanite $\left(\mathrm{Ca}_{2} \mathrm{~B}_{6} \cdot \mathrm{O}_{11} \cdot 5 \mathrm{H}_{2} \mathrm{O}\right)$, containing $35-40 \% \mathrm{~B}_{2} \mathrm{O}_{3}$, is a natural mineral that is less soluble and can be applied to the soils that have probability of leaching. It has moderate water solubility, so its application can supply boron to plants for longer periods and may become suitable as a controlled-release material at sites of high leaching potential (Dobermann and Fairhurst, 2000). Athough, slower rate of release of boron from colemanite is advantageous in reducing leaching losses, it should be enough to meet the requirements of crop timely. Colemanite has been found as an effective source of boron for wheat, maize, rice and sunflower crops (Saleem et al., 2011a; Muhammad et al., 2013; Sahin, 2014; Gandahi et al., 2016; Saleem et al., 2016a and Saleem et al., 2016b). However, information on the use of alternative sources like colemanite as boron fertilizers for potato crop in Indian soil is lacking. Hence, a laboratory incubation study using borax and colemanite was conducted to test the release of boron in the soil and availability of boron to plants was studied in pot experiments.

\section{Materials and Methods}

Soil incubation study: Release of boron from colemanite powder ( $11 \%$ boron) having 150 mesh size and laboratory grade borax ( $10.5 \%$ boron) was studied in slightly acidic soils of Shimla. Important physicochemical properties of the soil are given in Table 1. The soil was sandy loam in texture, acidic in nature, high in organic carbon content and marginally deficient in available boron. Borax and colemanite were thoroughly mixed in one kilogram soil on dry weight basis in plastic containers @1.25 and $2.5 \mathrm{mg} \mathrm{kg}^{-1}$ soil and soil moisture was maintained at $80 \%$ field capacity. Soil samples were collected for 6 weeks and analyzed for hot-water extractable boron following the method of Bingham (1982). Boron in soil extracts were measured calorimetrically using azomethine-H and ICP-OES. Percent rate of boron release was calculated after deducting the extractable boron content of control treatment from the highest value of extractable boron obtained from the respective source during the incubation study.

Pot experiment study: This study was carried out in a glasshouse in an acidic soil, marginally deficient in available boron during 2016-2017 at ICAR-CPRI, Shimla. Kufri Chandermukhi variety was planted in plastic pots containing $10 \mathrm{~kg}$ soil (dry weight basis). Boron from borax and colemanite were applied @ 2.5 to 5.0 and $7.5 \mathrm{~kg} \mathrm{ha}^{-1}$ and mixed in a band in upper $10 \mathrm{~cm}$ of soil and $10 \mathrm{~cm}$ away from the seed piece. The soil moisture was maintained at $80 \%$ field capacity by weighing the pots and adding distilled water. Boron content in leaf blades was determined 30 and 75 days after emergence. Hand held SPAD meter was used for determining chlorophyll content in leaves. The numerical SPAD values are proportional to chlorophyll content in leaves. After harvest, the soil in the pots was allowed to remain as such till next year for residual effect studies. Pot experiment for residual effects was conducted during April-June, 2017. Before planting, the soil of each pot was mixed thoroughly in a plastic tray separately and hot water extractable. The boron content in soil was determined by the method of Waston (1988). Boron concentration in leaves was determined after ashing one gram of dried leaf powder at $550^{\circ} \mathrm{C}$ in silica crucibles. Ten $\mathrm{ml}$ of $2 \mathrm{~N} \mathrm{HCl}$ was added to the ashed sample and the mixture was heated at $70^{\circ} \mathrm{C}$ to drive off the $\mathrm{HCl}$. After cooling, the mixture was dissolved in distilled water and filtered. Leaf boron concentration was measured by ICP-OES. The data on soil incubation studies on boron sources were statistically analysed by using two factor completely randomized block design and data on the effect of boron application on soil and plants in pot experiment studies were statistically analysed using single factor completely randomized block design.

\section{Results and Discussion}

Soil incubation study: Application of colemanite and borax in soil significantly increased hot water extractable boron content compared to its initial boron content (Table 2). Boron released from colemanite was slower compared to borax from the beginning of the study, and more than $80 \%$ added boron was recovered in the form of extractable boron from borax was achieved in one week's time (Fig. 1) whereas recovery from colemanite ranged from 63 to $67 \%$ after six weeks of incubation period. Release of boron in soil from colemanite and borax is related to their solubiliteis in water. The solubilities of colemanite and borax at $20^{\circ} \mathrm{C}$ are $5.10^{-3} \mathrm{M}\left(2.1 \mathrm{gl}^{-1}\right)$ and $0.11 \mathrm{M}\left(41.9 \mathrm{gl}^{-1}\right)$. Dissolution rate of borax is higher than colemanite (Saleem et al., 2011). Broschat (2008) found that boron released in sand columns followed the order: borax $>$ ulexite $>$ colemanite. The results of the present study, with respect to boron release, is in 


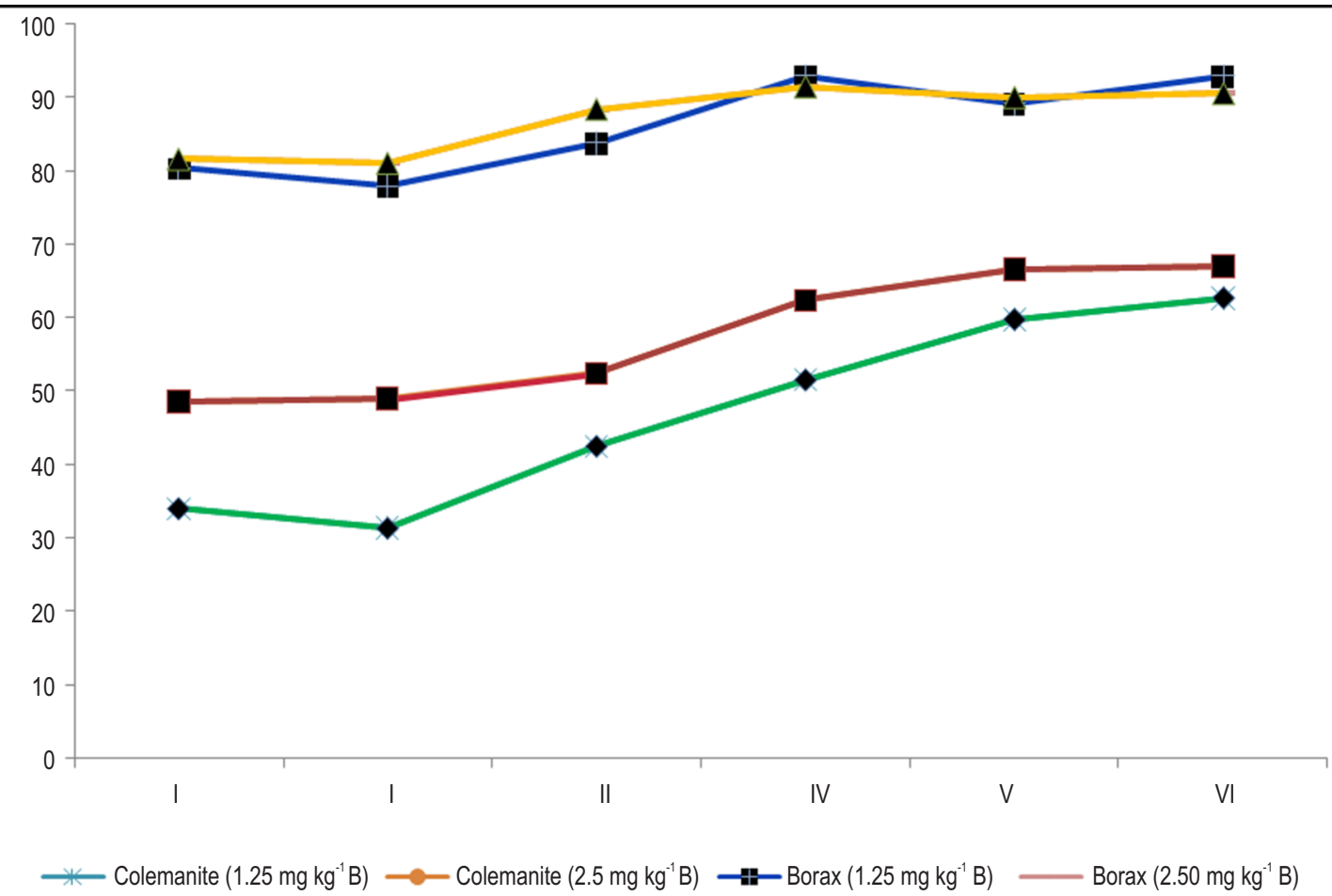

Fig. 1: Percent release of added boron from colemanite and borax in soil during six week (I-VI) incubation period (C.D. $(p=0.05)$ : Incubation period $($ Week $)=4.69$; Boron source=5.75).

Table 1: Important physico-chemical properties of the soil used for studies

\begin{tabular}{ll}
\hline Parameter & Value \\
\hline pH & 6.32 \\
Organic carbon (\%) & 2.0 \\
Hot water extractable boron $\left(\mathrm{mg} \mathrm{kg}^{-1}\right)$ & 0.46 \\
Clay $(\%)$ & 16.8 \\
Silt $(\%)$ & 10.5 \\
Sand $(\%)$ & 72.7 \\
\hline
\end{tabular}

agreement with the findings of Saleem et al. (2011) who also observed a slower rate of boron release from colemanite. Although the rate of boron release from colemanite in the present study was slower, however it was enough to meet the demand of potato crop, considering the accepted critical limit of $0.5 \mathrm{mg} \mathrm{kg}^{-1}$ for potato in most soils. In red lateritic soils the critical level of boron is $0.56 \mathrm{mg} \mathrm{kg}^{-1}$ (Sarangi et al., 2016). In soils with $\mathrm{pH}$ value less than 7.0 , the predominant form of boron in is $\mathrm{H}_{3} \mathrm{BO}_{3}$, which is highly susceptible to leaching (Quaggio et al., 2003) and boron release from colemanite at slower rate is beneficial to reduce the loss due to leaching. Saleem et al. (2011) reported reduced less of boron due to leaching from colemanite compared to borax.
Pot study : In pot study, both the sources (colemanite and borax) of boron increased the boron concentration in leaf blades significantly. Boron concentration in leaf tissues ranged from $42.3 \mathrm{mg} \mathrm{kg}^{-1}$ in colemanite treatment $\left(2.5 \mathrm{~kg} \mathrm{~B} \mathrm{ha}^{-1}\right)$ to $85.9 \mathrm{mg} \mathrm{kg}^{-1}$ in borax treatment $\left(7.5 \mathrm{~kg} \mathrm{~B} \mathrm{ha}^{-1}\right) 30$ days after emergence. No significant difference was noted between the two sources at 2.5 and $5.0 \mathrm{~kg} \mathrm{~B}$ $\mathrm{ha}^{-1}$. Application of $7.5 \mathrm{~kg} \mathrm{~B} \mathrm{ha}^{-1}$ as borax resulted in a significant increase in boron content in blades than colemanite (Table 3 ).

There were no significant differences between the two sources at lower rates of application, however, at 75 DAE increase in boron content was significantly higher in treatments receiving borax compared to colemanite, at all the three rates of boron application. A significant increase in hot water extractable boron was observed with the application of both the sources and boron content ranged from $0.4 \mathrm{mg} \mathrm{kg}^{-1}$ in control treatment to 3.25 $\mathrm{mg} \mathrm{kg}^{-1}$ in colemanite $\left(7.5 \mathrm{~kg} \mathrm{ha}^{-1}\right)$ and $3.56 \mathrm{mg} \mathrm{kg}^{-1}$ borax treated $\left(7.5 \mathrm{~kg} \mathrm{ha}^{-1}\right)$ soil (Table 4). The increase in hot water extractable boron was more in case of borax than colemanite. Gandahi et al. (2016) also observed significant increase in soil boron content after crop harvest due to application of colemanite.

The residual effects of boron were quite strong and boron concentration in leaves increased with increase in hot water 
Table 2: Effect of boron sources and incubation duration on extractable boron in soil ( $\left.\mathrm{mg} \mathrm{kg}^{-1}\right)$

\begin{tabular}{lllllll}
\hline \multirow{2}{*}{ Week/sources } & \multicolumn{2}{c}{ Colemanite } & \multicolumn{3}{c}{ Borax } & \multicolumn{2}{c}{ Control } \\
\cline { 2 - 7 } & $\mathbf{1 . 2 5}$ & $\mathbf{2 . 5 0}$ & $\mathbf{1 . 2 5}$ & $\mathbf{2 . 5 0}$ & $\mathbf{0 ~ B}$ & Mean \\
\hline I & 0.89 & 1.67 & 1.47 & 2.50 & 0.46 & 1.40 \\
II & 0.99 & 1.82 & 1.57 & 2.62 & 0.60 & 1.52 \\
III & 1.16 & 1.93 & 1.67 & 2.83 & 0.63 & 1.64 \\
IV & 1.23 & 2.15 & 1.75 & 2.87 & 0.59 & 1.72 \\
V & 1.35 & 2.26 & 1.71 & 2.88 & 0.60 & 1.76 \\
VI & 1.41 & 2.30 & 1.79 & 2.89 & 0.63 & 1.81 \\
Mean & 1.17 & 2.02 & 1.66 & 2.77 & 0.59 & \\
C.D. $(\mathrm{p}=0.05)$ & Factor A (week) $=0.056 ;$ Factor B (rate) $=0.051$; Factor (Ax B) $=0.126$ & &
\end{tabular}

Table 3: Direct effect of boron sources and rates on leaf boron content, plant height and SPAD value

\begin{tabular}{lllll}
\hline Treatment & $\begin{array}{l}\text { Boron in blades }\left(\mathrm{mg} \mathrm{kg}^{-1}\right) \\
\text { at 30 DAE }\end{array}$ & $\begin{array}{l}\text { Boron in blades }\left(\mathrm{mg} \mathrm{kg}^{-1}\right) \\
\text { at 75 DAE }\end{array}$ & $\begin{array}{l}\text { SPAD value } \\
\text { at 50 DAE }\end{array}$ & $\begin{array}{l}\text { Plant height }(\mathrm{cm}) \\
\text { at 75 DAE }\end{array}$ \\
\hline Control & 32.6 & 45.0 & 43.2 & 51.8 \\
Borax $\left(2.5 \mathrm{~kg} \mathrm{~B} \mathrm{ha}^{-1}\right)$ & 46.9 & 62.1 & 42.6 & 56.9 \\
Borax $\left(5.0 \mathrm{~kg} \mathrm{~B} \mathrm{ha}^{-1}\right)$ & 68.0 & 152.4 & 35.2 & 43.2 \\
Borax $\left(7.5 \mathrm{~kg} \mathrm{~B} \mathrm{ha}^{-1}\right)$ & 85.9 & 250.1 & 38.0 & 38.0 \\
Colemanite $\left(2.5 \mathrm{~kg} \mathrm{~B} \mathrm{ha}^{-1}\right)$ & 42.3 & 57.3 & 42.4 & 55.7 \\
Colemanite $\left(5.0 \mathrm{~kg} \mathrm{~B} \mathrm{ha}^{-1}\right)$ & 62.9 & 127.9 & 33.9 & 43.7 \\
Colemanite $\left(7.5 \mathrm{~kg} \mathrm{~B} \mathrm{ha}^{-1}\right)$ & 76.2 & 205.4 & 34.4 & 36.8 \\
C.D. $(\mathrm{p}=0.05)$ & 6.1 & 19.1 & 3.1 & 5.3 \\
\hline
\end{tabular}

Table 4: Residual effects of boron sources and rates on leaf boron content, plant height and SPAD value

\begin{tabular}{lllll}
\hline Treatment & $\begin{array}{l}\text { Extractable B }\left(\mathrm{mg} \mathrm{kg}^{-1}\right) \\
\text { in soil }\end{array}$ & $\begin{array}{l}\text { Boron concentration in } \\
\text { blades }\left(\mathrm{mg} \mathrm{kg}^{-1}\right) \text { at 75 DAE }\end{array}$ & $\begin{array}{l}\text { SPAD value } \\
\text { at 50 DAE }\end{array}$ & $\begin{array}{l}\text { Plant height }(\mathrm{cm}) \\
\text { at 75 DAE }\end{array}$ \\
\hline Control & 0.40 & 38.7 & 47.2 & 50.1 \\
Borax $\left(2.5 \mathrm{~kg} \mathrm{~B} \mathrm{ha}^{-1}\right)$ & 1.14 & 46.5 & 46.6 & 53.6 \\
Borax $\left(5.0 \mathrm{~kg} \mathrm{~B} \mathrm{ha}^{-1}\right)$ & 2.14 & 60.7 & 47.2 & 53.9 \\
Borax $\left(7.5 \mathrm{~kg} \mathrm{~B} \mathrm{ha}^{-1}\right)$ & 3.56 & 89.2 & 45.8 & 54.7 \\
Colemanite $\left(2.5 \mathrm{~kg} \mathrm{~B} \mathrm{ha}^{-1}\right)$ & 0.83 & 45.5 & 46.4 & 53.0 \\
Colemanite $\left(5.0 \mathrm{~kg} \mathrm{~B} \mathrm{ha}^{-1}\right)$ & 1.64 & 62.0 & 46.1 & 51.0 \\
Colemanite $\left(7.5 \mathrm{~kg} \mathrm{~B} \mathrm{ha}^{-1}\right)$ & 3.25 & 93.6 & 47.7 & 52.3 \\
C.D. $(p=0.05)$ & 0.17 & 6.5 & $\mathrm{NS}$ & $\mathrm{NS}$ \\
\hline
\end{tabular}

extractable boron content of the soil. Leaf blade boron content in residual effect studies ranged from $38.7 \mathrm{mg} \mathrm{kg}^{-1}$ in control treatment to $93.6 \mathrm{mg} \mathrm{kg}^{-1}$ colemanite treatment applied @ $7.5 \mathrm{~kg}$ $\mathrm{ha}^{-1}$ (Table 3.) revealing that colemanite was as effective as borax in supplying boron. Band application of boron @ 5.0 and $7.5 \mathrm{~kg} \mathrm{ha}^{-1}$ in soil reduced the plant height, and SPAD values (chlorophyll content) significantly and caused toxicity (leaf chlorosis followed by development of necrotic spots which started from leaf tip and progressed on the margins) which progressed to upper leaves during the growing period.

The symptoms of boron toxicity include yellowing of older leaves, drying leaf tissue at tips and margins and interveinal chlorosis. Boron toxicity exerts different effects on plants, such as altered metabolism, reduced root cell division, decreased lignin and suberin levels, oxidative stress, leaf chlorosis and necrosis which reduce photosynthesis and dry matter accumulation (Reid, 2007; Landi et al., 2012). Boron toxicity effects are closely associated with accumulation of high concentration in older leaves, especially at the margins of leaves. Boron introduced into the transpiration stream accumulates at the end of this stream (Tanaka and Fugiwara, 2007) and the symptoms of boron toxicity occur first at the margins of mature leaves, generally at the end of transpiration stream. Leaf chlorosis in seedlings of trifoliate orange is closely related to the concentration of free boron in leaf tissues (Wang et al., 2014). Boron toxicity affect the enzymes 
related to nitrogen assimilation and reduces the activity of nitrate reductase enzyme (Eraslan et al., 2007).

A decrease of $10 \%$ in barley root growth has been reported when soil solution boron concentration exceeded the values between 16 and $59 \mathrm{mg} \mathrm{l}^{-1}$ across different soils (Mertens et al., 2011). In the present study it appears that band application @ 5.0 and $7.5 \mathrm{~kg} \mathrm{ha}^{-1}$ caused high boron concentration in the root zone which led to higher boron uptake causing toxicity in the present study. Band application of boron results in greater boron concentration in leaf tissue than broadcast application (Gupta, 2006). To confirm the toxicity symptoms of boron in this study, boron concentration in apparently healthy (untreated) and necrotic basal leaves from the boron treated plants were compared 90 days after emergence. Boron concentration in leaf blades expressing chlorosis and severe necrosis symptoms as a result of application of boron at $7.5 \mathrm{~kg} \mathrm{ha}^{-1}$ from either source was $>300 \mathrm{mg} \mathrm{kg}^{-1}$. Boron content higher than $180 \mathrm{mg} \mathrm{kg}^{-1}$ is considered toxic for potatoes (Gupta, 2006). The rate and amount of boron release from colemanite was slower and less than borax in this study. However, the release of boron from colemanite was enough to meet the requirement of potato plants. Hence, colemanite can be used as an effective and slow release source of boron for potato plants.

\section{Acknowledgment}

Authors are thankful to the Director ICAR-CPRI, Shimla for providing the facilities and financial support for the institute project.

\section{References}

Bingham, F.T.: Boron. In: Methods of Soil Analysis, Part 2: Chemical and Mineralogical Properties (Eds.: A.L. Page, L.H. Miller and D.R. Keeney). American Society of Agronomy Madison, Wisc., pp. 431. 448 (1982)

Broschat, T.K.: Release rates of soluble and controlled release boron fertilizers. Hort. Technol., 18, 471-474 (2008).

Dobermann, $A$. and T. Fairhurst: Rice nutrient disorders and nutrient management. Manilla, Phillipines: Potash and Phosphate Institute (PPI), Potash and Phosphate Institute of Canada (PPIC) and International Rice Research Institute (2000).

Erasaln, F., A. Inal and M. Alpaslan: Boron toxicity alters nitrate reductase activity, proline accumulation, membrane permeability and mineral constituents of tomato and pepper plants. J. Plant Nut., 30, 981 994 (2007).

Gandahi, A.W., M. Saleem. F.S. Shaikh, G.M. Laghari and B. Mahmooda: Effect of colemanite ore as boron fertilizer on growth and yield of two wheat (Triticum aestivum L.) genotypes under field condition Int. J. Biosci., 9, 83-89 (2016).

Gupta, U.C.: Boron. In: Handbook of Plant Nutrition (Eds.: V. Allen, Barker and D.J. Pilbeam). CRC Press, Taylor and Francis Group, LLCBooks. USA, pp. 241-278 (2006).

Hugo, A. de M., A. Marco, A.R.A. Marco, B.P.I. Miralda, G. Janice de C. and C.A. Nóbrega Julio: Yield and quality of the potato in response of boron levels. Ciência e Agrotecnol., 31, 385-392 (2007)

Landi, M., E. Deglinnocenti, A. Pardossi and L. Guidi: Antioxidant and photosynthetic responses in plants under boron toxicity: A review. Am. J. Agr. Bio. Sci., 7, 255-270 (2012).

Mertens, J.L. Van Laer, P. Salaets and E. Smolders: Phytotoxic doses of boron in contrasting soils depend on soil water content. Plant Soil, 342, 73-82 (2011).

Muavviz, A., G. Avni and K. Fagerstedt: Does excess boron affect hormone levels of potato cultivars? Biotech. Biotechnol. Equip., 29, 887-891(2015)

Muhammad, S.S., Y.M. Khanif, I. Fauziah, A.W. Samsuri and B. Hafeez: Comparative evaluation of colemanite and sodium pentaborate as boron sources for rice grown in flooded calcareous soil. Sustain. Agric. Res., 2,135-141(2013).

Ozturk, O., S. Soylu, R. Ada, S. Gezgin and M. Babaoglu: Studies on differential response of spring canola cultivars to boron toxicity. J. Plant Nutr., 33,1141-1154 (2010).

Quaggio, J.A., J.D. Mattos, H. Cantarella and J.A. Tank: Fertilização com boro e zinco no solo em complementação à aplicação via foliar em laranjeira Pêra (Boron and zinc application on soil as complement to leaf spray on orange Pera trees). Pesq. Agropec.Bras., 38, 627-634 (2003).

Reid, R.J.: Identification of boron transporter genes likely to be responsible for tolerance to boron toxicity in wheat and barley. Plant Cell Physiol., 48, 1673-1678 (2007).

Sahin, S.: Effect of boron fertilizer applications on the growth and B, N uptake of maize (Zea mays L.) under different soils. J. Food Agric. Environ., 12, 1323-1327 (2014)

Sarangi, D.R., D. Jena and A.K. Chatterjee: Determination of critical limit of boron for rice, groundnut and potato crops in red and laterite soils of Odisha. Int. J. Priores. Stress. Manage., 7, 933-938 (2016).

Sarkar, D., B. Mandal and M.C. Kundu: Increasing use efficiency of boron fertilizers by rescheduling the time and methods of application for crops in India. Plant Soil, 301, 77-85 (2007).

Saleem, M., K.Y. Muhammad, I. Fauziah and A.W. Samsuri: Solubility and leaching of boron from borax and colemanite in flooded acidic soils. Commun. Soil Sci. PlantAnal., 42, 293-300 (2011).

Saleem, M., A. Arshadullah, A.W. Gandahi, S. Bhatti and M.S. Velo: Effectiveness of colemanite ore as boron source for sunflower (Helianthus annuus L.) oil content and yield. Sindh Uni. Res. J., 48, 931-934 (2016a)

Saleem, M., K. Gulab, A.W. Gandahi, S.M. Bhatti and S. Velo: Efficacy of colemanite ore as boron fertilizer for maize (Zea mays L.) growth and yield. Sci. Int., (Lahore), 28, 3071-3074 (2016b).

Sharma, J., Prince Kumar, V.K. Dua, V. Sharma., D. Kumar, S. Kumar, S. Rawal and M.A. Khan: Status of micronutrients in intensively cultivated potato growing soils of Punjab. Potato J., 44, 58-64 (2017)

Sharma, V.K. and R.P. Singh: A very significant increase in plant growth, nitrate assimilation and seed yield was recorded in organic matrix based SRF-II applied plants. J. Environ. Biol., 32, 619-24 (2011).

Tanaka, M. and T. Fujiwara: Physiological roles and transport mechanisms of boron perspectives from plants. Pflugers Arch. Eur. J. Physiol., 456, 671-677 (2007).

Wang, R., G. Liu, L. Liu and C. Jiang: Relationship between leaf chlorosis and different boron forms in trifoliate orange seedlings under excessive boron supply. Soil Sci. Plant Nutr., 60, 325-332 (2014).

Watson, M. E.: Recommended soil boron test. In: Recommended Chemical Soil Test Procedures for the North Central Region (Ed.: W. C. Dahnke). North Dakota Agric. Expt. Stn. Bull. No. 499, pp. 23-25(1988).

Zhao, Y.: Auxin biosynthesis and its role in plant development. Annu. Rev. Plant Biol., 64, 61-49 (2010). 